\title{
Effect of Growth Temperature on the Cryopreservation of Prototheca
}

\author{
By G. J. MORRIS \\ Institute of Terrestrial Ecology, Culture Centre of Algae and Protozoa, \\ 36 Storey's Way, Cambridge CB3 oDT
}

(Received 8 December 1975)

\begin{abstract}
SUMMARY
The temperature at which Prototheca spp. were grown determined their response to freezing to $-196^{\circ} \mathrm{C}$ and subsequent thawing. Cells cultured at $35^{\circ} \mathrm{C}$ were the most sensitive to freezing injury; at lower growth temperatures, resistance to freezing damage was seen. At all culture temperatures examined, the freezing tolerance varied with the age of the culture.
\end{abstract}

\section{INTRODUCTION}

Prototheca is a unicellular, colourless heterotrophic organism which has been classified as an apoplastidic relation of the genus Chlorella (Cooke, I968). On the basis of nutritional similarities (Pore, 1972) and cell-wall polysaccharide composition (Conte \& Pore, 1973), Prototheca spp. have been shown to be related to Chlorella protothecoides, the only species of the sub-genus Auxenochlorella (Shihira \& Krauss, 1965).

As Prototheca may be a pathogen of man and other animals (Emmons, Chapman \& Utz, 1970), cultures were maintained under liquid nitrogen rather than by serial passage. The advantages of the cryopreservation of algal cultures in maintaining the original properties of organisms and in reducing the possibility of contamination have already been described (Holm-Hansen, I963, I97I; Hwang \& Horneland, 1965).

In preliminary experiments, Prototheca spp. were found to be sensitive to the stress of freezing to and thawing from $-196^{\circ} \mathrm{C}$. It was therefore decided to determine whether Prototheca could be made tolerant of freezing by cold acclimatization as can C. fusca var. vacuolata (Morris, 1976 b), benthic seaweeds (Bird \& McLachlan, 1974; Lyutova et al., 1967) and higher plants (reviewed by Levitt, 1972). It has also been reported that the recovery following freezing and thawing of Escherichia coli (Toyokawa \& Hollander, 1956), Chlorella spp. (Morris, 1976 a,b) and Tetrahymena (Osborne \& Lee, 1975) varies with the age of the culture. Because of the different growth rates of Prototheca at the experimental temperatures studied, it was necessary to determine tolerance of freezing on successive days of culture. As survival following freezing and thawing is related to the rate of cooling (reviewed by Mazur, 1970), the effect of rates of cooling to $-196{ }^{\circ} \mathrm{C}$ on cells grown at different temperatures was examined. Finally, the method of preservation developed for one strain of Prototheca was applied to seven other strains.

\section{METHODS}

Cells. All strains of Prototheca were obtained from the Culture Centre of Algae and Protozoa (CCAP), whose system of numbering is employed. Cells of $P$. chlorelloides CCAP263/I were used to develop preservation techniques.

Cell culture. Cells were grown in $\mathrm{I} \%(\mathrm{w} / \mathrm{v})$ tryptone-I \% (w/v) glucose broth. Conical 
flasks (I00 ml) were inoculated with $\mathrm{I} \mathrm{ml}$ of a stationary phase culture grown for 7 to 10 days, at $25{ }^{\circ} \mathrm{C}$, and incubated in the dark.

Freezing and thawing. Cells from liquid culture were used without further preparation. The cell suspension ( $\mathrm{I} \mathrm{ml}$ ) was placed in $12 \times 35 \mathrm{~mm}$ sterile polypropylene tubes (Sterilin, Richmond, Surrey), cooled at different rates to $-60^{\circ} \mathrm{C}$ using the technique previously described (Morris \& Farrant, 1972), and then cooled rapidly to $-196{ }^{\circ} \mathrm{C}$ in liquid nitrogen. The cooling rate was determined between -5 and $-60{ }^{\circ} \mathrm{C}$ using a separate sample with a copper-constantan thermocouple ( 28 s.w.g.) connected to a Kipp-Zonen potentiometric recorder (Model $\mathrm{BD}_{5}$ ). Cells were thawed by rapid agitation of the tube in a water bath at $25^{\circ} \mathrm{C}$ until all ice had melted.

Thermal shock. Samples of cells $(\mathrm{I} \mathrm{ml}$ ) in polypropylene tubes were incubated in a water bath at $25^{\circ} \mathrm{C}$ for $30 \mathrm{~min}$ and then placed in a stirred ice-water bath for $15 \mathrm{~min}$; this produced an exponential and reproducible rate of cooling.

Viability assay. Samples of exponential dilutions of the cells $(\mathrm{I} \mathrm{ml})$ in tryptone-glucose medium were pipetted into sterile Petri dishes $(90 \mathrm{~mm})$, and $25 \mathrm{ml}$ of $1.5 \%(\mathrm{w} / \mathrm{v})$ agar in tryptone-glucose medium $\left(40\right.$ to $42{ }^{\circ} \mathrm{C}$ ) was added. After the cells had been dispersed by gentle agitation, the agar was allowed to solidify, and the plates were inverted and incubated at $25^{\circ} \mathrm{C}$. After $72 \mathrm{~h}$, colonies were counted. The efficiency of plating for unfrozen cells, as determined by haemocytometer counts, was always greater than $95 \%$.

Five replicates were examined for each treatment.

\section{RESULTS}

\section{Effect of growth temperature}

Flasks were inoculated with $P$. chlorelloides and incubated at $4,15,25$ or $35^{\circ} \mathrm{C}$. On successive days of culture, the cells were cooled to $0^{\circ} \mathrm{C}$ or to $-196^{\circ} \mathrm{C}$. Two methods of cooling to $-196^{\circ} \mathrm{C}$ were examined: rapid cooling, at a rate of $212 \pm 17{ }^{\circ} \mathrm{C} \mathrm{min}{ }^{-1}$, by direct immersion of the tube in liquid nitrogen, $(N=54)$; and slow cooling, at a rate of $0.314 \pm 0.011{ }^{\circ} \mathrm{C} \mathrm{min}^{-1}$, to $-60^{\circ} \mathrm{C}$ followed by transfer to liquid nitrogen $(N=48)$.

Under no experimental condition was there a loss of viability upon reduction in temperature from 25 to $0^{\circ} \mathrm{C}$ (thermal shock). This is in contrast to the report that C.protothecoides in the exponential phase of growth is susceptible to thermal shock damage (Morris, 1976a).

Prototheca chlorelloides did not survive rapid cooling to $-196{ }^{\circ} \mathrm{C}$ (recovery $<0.1 \%$ ) following growth at 25 or $35^{\circ} \mathrm{C}$ (Fig. 1). However, cells cultured at lower temperatures showed a small but significant increase in recovery (Fig. 2). Following the slower rate of cooling, viable cells were recovered upon thawing from all cultures examined (Figs. I and 2). Decreasing the temperature of culture led to an increase in resistance to freezing and thawing. These results agree with those obtained for other algae (Bird \& McLachlan, 1974; Lyutova et al., 1967; Morris, 1976b) and higher plants (Levitt, 1972). At all experimental temperatures, freezing tolerance varied with the age of the culture (Figs. I and 2).

\section{Effect of rate of cooling}

Prototheca chlorelloides was cultured at 4, I5, 25 and $35^{\circ} \mathrm{C}$ for periods, determined from Figs. I and 2, which gave cells with maximum freezing tolerance at each temperature. The effect on these cells of the rate of cooling to $-196^{\circ} \mathrm{C}$ was then determined. With all cultures, the highest recovery was obtained after the slowest cooling rate $\left(0.3{ }^{\circ} \mathrm{C} \mathrm{min}{ }^{-1}\right)$; recovery 


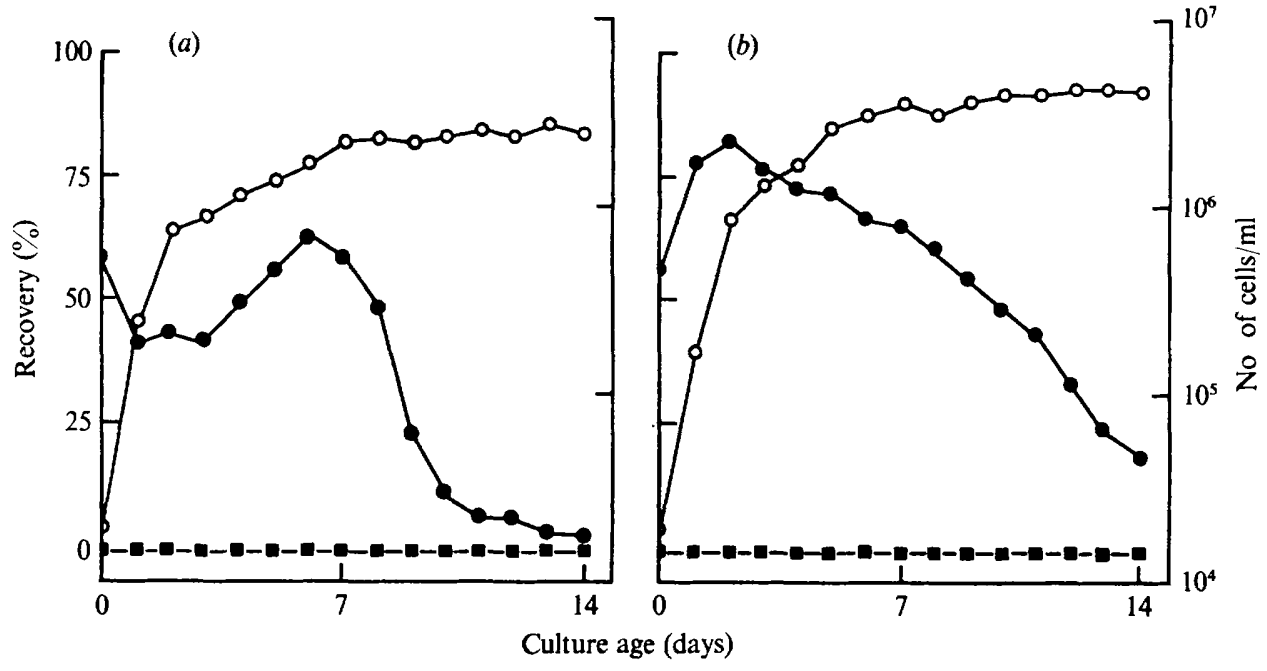

Fig. I. Recovery of $\boldsymbol{P}$. chlorelloides following freezing and thawing from $-196^{\circ} \mathrm{C}$ on different days of culture at (a) $35{ }^{\circ} \mathrm{C}$ or (b) $25^{\circ} \mathrm{C}$. Cells were cooled at a rate of $0.3{ }^{\circ} \mathrm{C} \mathrm{min}^{-1}$ (O) or $212{ }^{\circ} \mathrm{C} \mathrm{min}^{-1}$ (G). Growth curves of unfrozen control cells are included $(O)$. In this and subsequent figures, standard errors are not given, but were always less than $\pm 2 \%$ recovery.

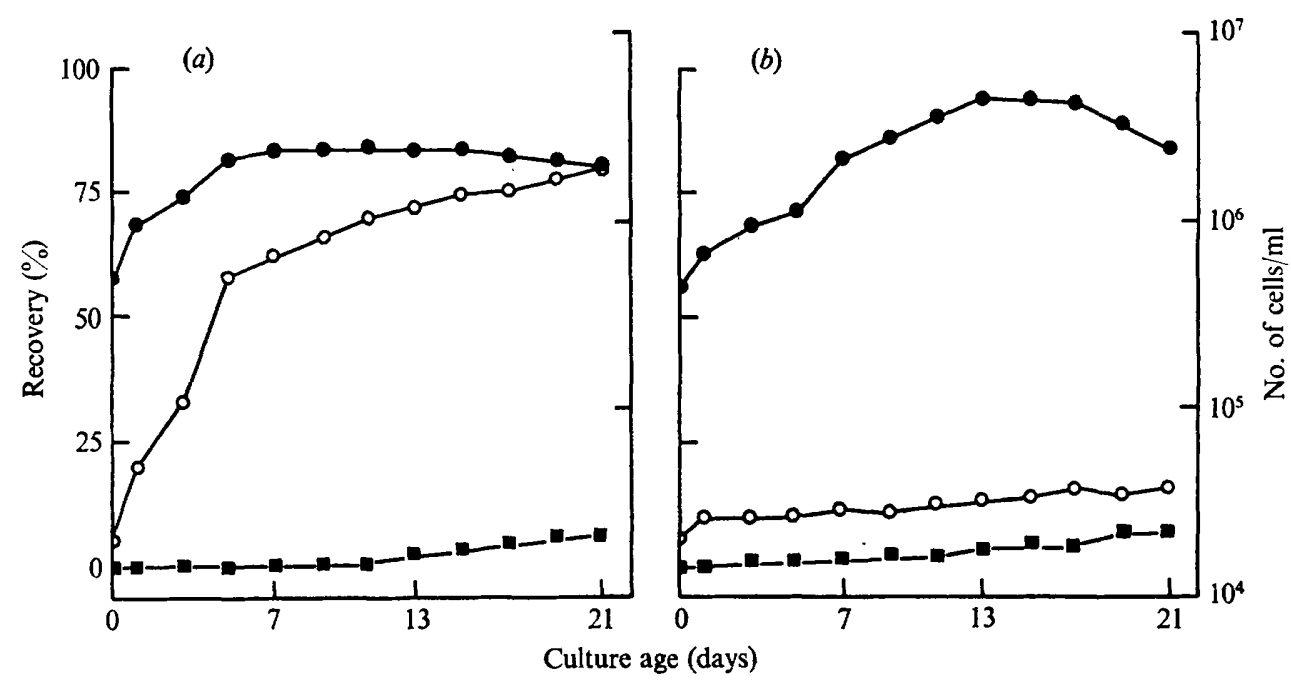

Fig. 2. Recovery of $P$. chlorelloides following freezing and thawing from $-196{ }^{\circ} \mathrm{C}$ on different days of culture at $(a) 15{ }^{\circ} \mathrm{C}$ or $(b) 4^{\circ} \mathrm{C}$. Cells were cooled at a rate of $0.3^{\circ} \mathrm{C} \mathrm{min}^{-1}(0)$ or $212{ }^{\circ} \mathrm{C} \mathrm{min}^{-1}$ (a). Growth curves of unfrozen control cells are included $(O)$.

decreased as the rate increased (Fig. 3). At all cooling rates studied, the recovery decreased as the temperature of the culture increased.

\section{Cryopreservation of other Prototheca spp.}

From the results illustrated in Figs. I to 3, it was decided that the best method for routine cryopreservation of Prototheca spp. was as follows. Cells were grown for 14 days at $4{ }^{\circ} \mathrm{C}$, cooled at a rate of $0.3{ }^{\circ} \mathrm{C} \mathrm{min}-1$ to $-60{ }^{\circ} \mathrm{C}$ and then transferred to liquid nitrogen. The recoveries of viable cells of eight strains of Prototheca preserved by this technique are given 


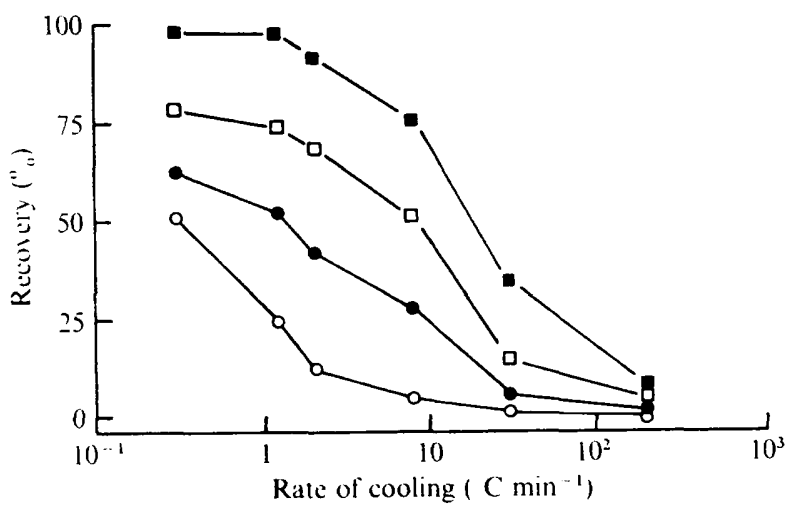

Fig. 3. Recovery of $P$. chlorelloides after cooling at different rates to $-196{ }^{\circ} \mathrm{C}$. Cells were cultured for 7 days at $35^{\circ} \mathrm{C}(\mathrm{C}), 3$ days at $25^{\circ} \mathrm{C}(\mathrm{O})$, and for $\mathrm{I} 4$ days at $15{ }^{\circ} \mathrm{C}(\square)$ or $4{ }^{\circ} \mathrm{C}(\mathbf{a})$.

Table I. Recovery following freezing and thawing of eight strains of Prototheca Cells were grown at $4{ }^{\circ} \mathrm{C}$ for 14 days, cooled at a rate of $0.3^{\circ} \mathrm{C} \min ^{-1}$ to $-60^{\circ} \mathrm{C}$ and then transferred to liquid nitrogen for 7 days.

CCAP
strain no
$263 / 1$
$263 / 2$
$263 / 3 a$
$263 / 3 b$
$263 / 4$
$263 / 5$
$263 / 6$
$263 / 7$

Species

P. chlorelloides

P. moriformis

$P$. portoricensis

$P$. portoricensis

$P$. portoricensis var. trisporus

P. zopfii

P. krugeri

Prototheca sp.

$$
\begin{gathered}
10^{-5} \times \text { no. of } \\
\text { cells } / \mathrm{ml} \\
\text { before freezing }
\end{gathered}
$$

Recovery $(\%)$

$\begin{array}{cc}23 & 89 \\ 43 & 84 \\ 2 \cdot 7 & 34 \\ 2 \cdot 5 & 62 \\ 3 \cdot 4 & 46 \\ 1 \cdot 1 & 37 \\ 1 \cdot 5 & 48 \\ 3 \cdot 5 & 68\end{array}$

in Table I. With all strains, the recovery upon thawing was greater than $30 \%$ and the number of viable cells recovered $/ \mathrm{ml}$ exceeded $10^{4}$, sufficient inoculum for a new culture. Long-term stability studies on these frozen samples are now in progress.

\section{DISCUSSION}

Previous studies on freezing tolerance at sub-optimal growth temperatures have been confined to photosynthetic organisms. Our results show that a similar cold acclimatization process occurs in the apoplastidic alga Prototheca.

The biochemical mechanism of this increase in freezing tolerance is not fully understood (reviewed by Levitt, 1972). It is generally assumed that cellular membranes are the primary sites of damage during freezing and thawing. Membrane lipids change from a liquid crystalline to a gel structure upon reduction in temperature (reviewed by Grant, 1975). The extent of these phase separations and the temperature at which they occur depend both on the lipid composition and the degree of fatty-acid saturation of the membrane (James \& Branton, 1973; Schechter, Letellier \& Gulik-Krzywicki, 1974). It has been suggested that the increase in the degree of unsaturation of membrane fatty acids at low growth temperatures in bacteria (Marr \& Ingram, 1962; Farrell \& Rose, 1967), Chlorella (Patterson, 1970) and higher plants (Gerloff, Richardson \& Stahmann, 1966; Siminovitch et al., I968; Kuiper, 1970), or the increase in total membrane lipids at low growth temperatures (Singh, de la Roche \& Siminovitch, 1975; Morris, $1976 b$ ) may be responsible for the cryoprotective effect.

This process of cold acclimatization provides a simple method for cryopreservation of 
Prototheca without the addition of cryoprotective compounds. Cells may be used directly upon thawing without washing and centrifuging. Application of this technique as a general method for the cryopreservation of algae and protozoa is now in progress.

\section{REFERENCES}

Bird, C. J. \& McLachlan, J. (1974). Cold-hardiness of zygotes and embryos of Fucus (Phaeophyceae, Fucales). Phycologia 13, 214-225.

CONTE, M. V. \& PoRE, R. S. (I973). Taxonomic implications of Prototheca and Chlorella cell wall polysaccharide characterization. Archives of Microbiology 92, 227-233.

COOKE, W.B. (1968). Studies in the genus Prototheca. I. Literature review. Journal of Elisha Mitchell Scientific Society 84, 213-216.

Emmons, C. W., Chapman, C. H. \& Utz, J. P. (1970). Medical Mycology. Philadelphia, Pennsylvania: Lea \& Febiger.

FARRELL, J. \& RoSE, A. H. (1967). Temperature effects on micro-organisms. In Thermobiology, pp. 142-169. Edited by A. H. Rose. London: Academic.

Gerloff, E. D., Richardson, T. \& Stahmann, M. A. (1966). Changes in fatty acids of alfalfa roots during cold hardening. Plant Physiology 4I, I 280-I284.

GRANT, C. W. M. (1975). Lipid lateral phase separations; spin label and freeze-fracture electron microscopy studies. Biophysical Journal 15, 949-952.

Holm-HANSEN, O. (1963). Viability of blue-green and green algae after freezing. Physiologia plantarum I6, 530-540.

Holm-HANSEN, O. (1971). Preservation by freezing and freeze-drying. In Phycological Methods, pp. 195-205. Edited by J. R. Stein. Cambridge: University Press.

Hwang, S. \& HoRneland, W. (1965). Survival of algal cultures after freezing by control and uncontrolled cooling. Cryobiology I, 305-3I I.

JAMES, R. \& BRANTON, D. (I973). Lipid and temperature-dependent structural changes in Acholeplasma laidlawii cell membranes. Biochimica et biophosica acta 323, 378-390.

KUIPER, P. J. C. (1970). Lipids in alfalfa leaves in relation to cold hardiness. Plant Physiology 45, 684-686.

LEVITT, J. (1972). Responses of plants to environmental stresses. New York and London: Academic.

LyUtova, H. I., Zavadskaya, I. G., LukinTSKayA, N. F. \& FeldMan, N. L. (1967). Temperature adaption of cells of marine and freshwater algae. In The Cell and Environmental Temperature, pp. 166-172. Edited by A. S. Troshin. Oxford: Pergamon.

MARR, A. G. \& INGRAM, J. L. (1962). Effect of temperature on the composition of fatty acids in Escherichia coli. Journal of Bacteriology 84, I260-1 267.

Mazur, P. (1970). Cryobiology: The freezing of biological systems. Science, New York 168, 939-949.

MORRIS, G. J. (1976a). The cryopreservation of Chlorella. I. Interactions of rate of cooling, protective additive and warming rate. Archives of Microbiology 107, 57-62.

MoRris, G. J. (1976b). The cryopreservation of Chlorella. 2. Effect of growth temperature on freezing tolerance. Archives of Microbiology (in the Press).

MoRRIS, G. J. \& FarRanT, J. (1972). Interactions of cooling rate and protective additive on the survival of washed human erythrocytes frozen to $-196^{\circ} \mathrm{C}$. Cryobiology 9, 173-181.

OSBORNE, J. A. \& LEE, D. (1975). Studies on conditions required for optimum recovery of Tetrahymena pyriformis strain $\mathrm{s}$ (phenoset A) after freezing to and thawing from $-196{ }^{\circ} \mathrm{C}$. Journal of Protozoology 22, 233-236.

Patterson, G. W. (1970). Effect of culture temperature on fatty acid composition of Chlorella sorokiniana. Lipids 5, 597-600.

PORE, R. S. (1972). Nutritional basis for relating Prototheca and Chlorella. Canadian Journal of Microbiology 18, II 75-I 177 .

SHECHTER, E., LETELLIER, E. \& GULIK-KRZYWICKI, T. (1974). Relations between structure and function in cytoplasmic membrane vesicles isolated from an Escherichia coli fatty-acid auxotroph. High-angle X-ray diffraction, freeze etch electron microscopy and transport studies. European Journal of Biochemistry 49, $6 \mathrm{I}-76$.

Shinira, I. \& Krauss, R. W. (1965). Chlorella: Physiology and Taxonomy of Forty-one Isolates. College Park, Maryland: University of Maryland Press.

Siminovitch, D., Rheaume, B., Pomeroy, K. \& Lepage, M. (1968). Phospholipid, protein and nucleic acid increases in protoplasm and membrane structures associated with development of extreme resistance in black locust tree cells. Cryobiology 5, 202-225.

SingH, J., DE LA RoCHE, I. A. \& Siminovitch, D. (1975). Membrane augmentation in freezing tolerance of plant cells. Nature, London 257, 699-700.

TOYOKAWA, K. \& Hollander, D. H. (1956). Variation in sensitivity of Escherichia coli to freezing damage during the growth cycle. Proceedings of the Society for Experimental Biology and Medicine 92, 499-500. 